\title{
PEDULI DAN PENCEGAHAN COVID-19 DI RT. 009, RW. 016, KELURAHAN BAKTI JAYA, KECAMATAN SUKMA JAYA, DEPOK
}

\author{
Yelvi $^{1 \Xi}$, Erlina Yanuarini' ${ }^{2}$, Tri Wulan Sari ${ }^{3}$ \\ 1,2,3 Jurusan Teknik Sipil Politeknik Negeri Jakarta, \\ Jl. Prof. Dr. G. A. Siwabessy, Depok, Jawa Barat, 16424

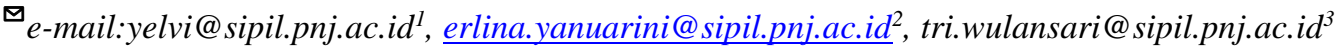

\begin{abstract}
COVID-19 in Indonesia was first discovered in Depok, West Java. Two Depok Residents were declared positive COVID-19 on March 2, 2020. Since the announcement of the first case. Depok is now a city in West Java Province with the most COVID-19 positive cases. To suppress the spread of COVID-19, the Depok city government imposed large-scale social restrictions (PSBB) on April 15, 2020. The public's impact is strongly felt due to the enactment of PSBB in terms of the economy. Many people have to lose their jobs. Public awareness in maintaining cleanliness and health is also still lacking due to the public's inability to buy masks and hand soap whose prices soar. The Jakarta State Polytechnic Civil Engineering Department's Road and Bridge Design Engineering Program (TPJJ) is motivated to participate in assisting communities affected by COVID-19 by holding community service activities. Sukmajaya sub-district is the area in Depok that is most infected with COVID-19. Based on this, TPJJ Study Program will assist in providing public sinks, the distribution of masks, hand soap, and food at RT 009 RW 016 Bakti Jaya subdistrict Sukmajaya Sub-District, Depok. It is hoped that this activity can reduce the spread of COVID19 and can ease the burden on people who are experiencing economic hardship.
\end{abstract}

Keywords-- COVID-19, PSBB, Masks, Hand Soap

\begin{abstract}
Abstrak
Kota Depok merupakan kota pertama kali ditemukannya kasus COVID-19 di Indonesia. Dua orang warga Depok dinyatakan positif COVID-19 pada tanggal 2 Maret 2020. Sejak diumumkannya kasus pertama tersebut. Depok sekarang menjadi kota di Provinsi Jawa Barat dengan kasus positif COVID-19 terbanyak. Demi menekan penyebaran COVID-19 Pemerintah Daerah Kota Depok memberlakukan Pembatasan Sosial Berskala Besar (PSBB) pada tanggal 15 April 2020. Dampak yang sangat dirasakan oleh masyarakat akibat pemberlakuan PSBB ini adalah dari segi ekonomi. Bahkan banyak yang harus kehilangan pekerjaan. Kesadaran masyarakat dalam menjaga kebersihan dan kesehatan juga masih kurang. Hal ini juga disebabkan karena ketidakmampuan dari masyarakat untuk membeli masker dan hand sanitizer yang harganya melambung tinggi. Program Studi Teknik Perancangan Jalan dan Jembatan (TPJJ) Jurusan Teknik Sipil Politeknik Negeri Jakarta termotivasi untuk ikut berpartisipasi dalam memberikan bantuan kepada masyarakat yang terdampak akibat COVID-19 ini dengan mengadakan kegiatan pengabdian kepada masyarakat. Kecamatan Sukmajaya merupakan wilayah di Kota Depok yang paling banyak terjangkit COVID-19. Berdasarkan hal tersebut Program Studi TPJJ akan memberikan bantuan berupa penyediaan wastafel umum, poster mengenai protocol COVID-19, pembagian masker, hand soap, dan sembako di RT 009 RW 016 Kelurahan Bakti Jaya Kecamatan Sukmajaya, Depok. Diharapkan kegiatan ini dapat mengurangi penyebaran COVID-19 dan dapat meringankan beban masyarakat yang sedang mengalami kesulitan ekonomi.
\end{abstract}

Kata kunci-- COVID-19, PSBB, Masker, Hand Soap 


\section{Pendahuluan}

\section{Latar Belakang}

Pandemi COVID-19 semakin meluas di seluruh daerah di Indonesia. Provinsi kedua terbanyak yang memiliki kasus positif di Indonesia adalah Jawa Barat (Mantalean, 2020). Dari website resmi Pemerintah Kota Depok per tanggal 13 April 2020, sudah ada 124 orang positif Covid-19, sembuh 11 orang, meninggal 15 orang, 698 Pasien Dalam Pengawasan (PDP), 2388 Orang Dalam Pengawasan (ODP ), 677 Orang Tanpa Gejala (OTG) (Pemerintah Kota Depok, 2020). Pemerintah kota Depok menerapkan tindakan Pembatasan Sosial Berskala Besar (PSBB) mulai tanggal 15 April 2020 untuk menekan penularan Covid19 (Iqbal, 2020).

Dalam rangka mendukung upaya pemerintah Kota Depok tersebut, Program Studi Teknik Perancangan Jalan dan Jembatan ikut berpartisipasi memberikan kontribusinya. Kontribusi yang diberikan berupa kegiatan pengabdian kepada masyarakat. Daerah yang dipilih dalam pelaksanaan kegiatan ini yaitu daerah yang berada dalam zona merah terdampak COVID-19 di Kota Depok seperti Kelurahan Bakti Jaya. Kelurahan Bakti Jaya merupakan salah satu Kelurahan di Kecamatan Sukma Jaya, Kota Depok, lihat Gambar 1. Kelurahan Bakti Jaya ini terletak sekitar 4,8 km dari Kampus Politeknik Negeri Jakarta seperti yang ditunjukkan pada Gambar 1.2. Dari peta persebaran Covid-19 (lihat Gambar 2 ), pada awal bulan April 2020 ini terkonfirmasi ada 5 orang positif Covid-19, 27 Pasien Dalam Pengawasan (PDP), 71 Orang Dalam Pengawasan (ODP ), 19 Orang Tanpa Gejala (OTG) di Kelurahan Bakti Jaya, Kecamatan Sukma Jaya, Depok (Pemerintah Kota Depok, 2020).

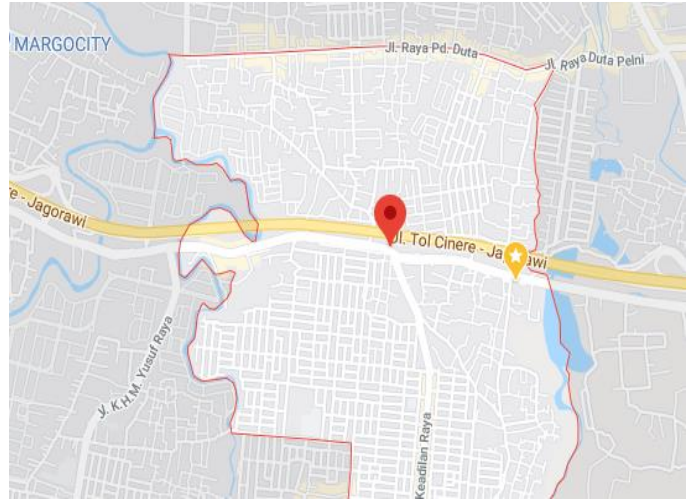

Gambar 1. Lokasi Kelurahan Bakti Jaya (Google Map, 2020)

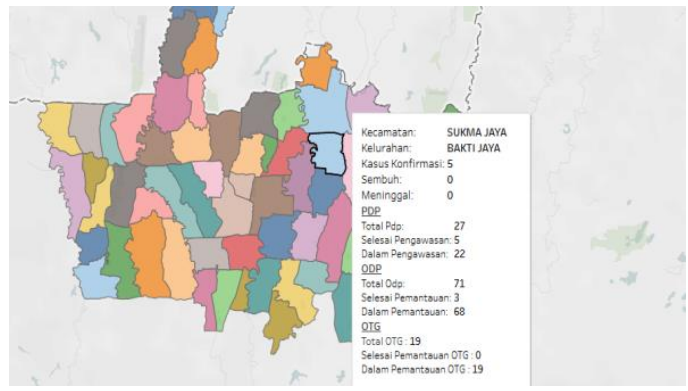

Gambar 2. Peta Persebaran Covid-19 di Kelurahan Bakti Jaya (Pemerintah Kota Depok, 2020)

Warga Kelurahan Bakti Jaya, khususnya di RT 009, RW 016 terdiri dari 65 KK (Kartu Keluarga). Dalam satu rumah bisa dihuni sampai dengan 4 KK. Pendidikan warga di sini untuk tingkat SD sebanyak $20 \%$, tingkat SP 30 $\%$, tingkat SMA $45 \%$, dan sisanya Sarjana $5 \%$. Pekerjaan warga di RT ini mayoritas adalah tukang ojek, pedagang kecil, dan pensiunan.

Permasalahan yang dihadapi warga RT 009, RW 016, Kelurahan Bakti Jaya, Kecamatan Sukma Jaya Depok akibat pandemi Covid-19 ini adalah

- Kecemasan warga akibat adanya warga di Kelurahan Bakti Jaya yang dinyatakan positif terinfeksi Covid-19

- Lingkungan yang padat penduduk ini memungkinkan penularan Covid-19 menjadi lebih mudah

- Warga yang profesinya sebagai tukang ojek dan pedagang kecil kehilangan pemasukan harian mereka dengan sangat signifikan 
- Harga sembako yang semakin meningkat sementara pengasilan warga menurun

- Ketersediaan masker dan hand soap yang sulit didapatkan

Berdasarkan permasalahan tersebut di atas kegiatan Pengabdian Masyarkat Program Studi Teknik Perancangan Jalan dan Jembatan (TPJJ), Jurusan Teknik Sipil Politeknik Negeri Jakarta ini difokuskan pada penyediaan wastafel, pemberian sembako, masker, dan hand sanitizer kepada warga RT 009, RW 016, Desa Bakti Jaya, Kecamatan Sukma Jaya, Depok. Untuk wastafel saat ini sebenarnya sudah disediakan di masjid tapi masih dalam kondisi seadanya menggunakan ember sebagai bak airnya. Oleh sebab itu Tim Pengabdian Masyarakat ingin menyediakan wastafel yang lebih permanen, sehingga dapat dipergunakan untuk jangka waktu yang lama. Kegiatan ini diharapkan dapat membantu meringankan permasalahan yang dialami oleh warga di RT ini. Kegiatan ini juga diharapkan dapat mencegah penularan Covid-19 sehingga tidak ada korban lagi yang positif Covid-19 khusunya di Kelurahan Bakti Jaya ini

\section{Tujuan Program}

Tujuan program Kegiatan Pengabdian Masyarkat Program Studi Teknik Perancangan Jalan dan Jembatan, Jurusan Teknik Sipil Politeknik Negeri Jakarta adalah

1) Penyediaan wastafel umum

2) Pembagian sembako, masker, dan hand soap khususnya di RT 009, RW 016, Kelurahan Bakti Jaya, Kecamatan Sukma Jaya, Depok.

\section{Deskripsi Program}

Program ini merupakan inisiasi dari masyarakat RT 009, RW 016, Kelurahan Bakti Jaya, Kecamatan Sukma Jaya, Depok sebagai Mitra Desa yang mengajukan usulan supaya dapat dibantu dalam menangani permasalahan pencegahan Covid-19 di wilayahnya. Usulan tersebut kemudian diterima oleh Tim Pengabdian Kepada Masyarakat untuk selanjutnya bersama dengan usulan dari masyarakat yang lain ditelaah dan dipilih berdasarkan beberapa kriteria yang sudah ditentukan.

\section{Solusi Pemecahan}

\section{Aplikasi IPTEKS}

Aplikasi ilmu pengetahuan, teknologi, dan senin (IPTEKS) dalam kegiatan Pengabdian Kepada Masyarakat di RT 009, RW 016, Kelurahan Bakti Jaya, Kecamatan Sukma Jaya, Depok adalah

- Penyediaan wastafel yang dibuat dari drum dan dilengkapi dengan tempat sabun cuci tangan dan tempat tissu.

- Pembelian masker, hand soap, dan bahan sembako melalui aplikasi belanja online untuk menghindari kontak langsung dengan banyak orang bila dilakukan di pasar tradisional.

\section{Teori yang Mendasari}

Ketersediaan wastafel umum di lingkungan masyarakat dapat mengurangi penularan virus Covid-19 (Jamkesnews, 2020). Masker juga dapat mengurangi penularan virus korona karena mencegah percikan yang disebabkan oleh percikan tetesan dan aerosol orang yang positif Covid-19 (Leung, 2020). Hand soap juga dibutuhkan untuk mengurangi resiko tertular Covid-19 saat/setelah tangan bersentuhan dengan benda yang kemungkinan terkontaminasi oleh Covid-19 (Pranita, 2020). Pemberian sembako ini diharapkan dapat membantu kebutuhan pokok Warga di RT ini selama beberapa waktu sehingga dapat meringankan beban warga terutama yang kehilangan pemasukan harian mereka akibat diterapkannya PSBB. 
Keterlibatan Mitra dan Sustainability

Mitra Program Pemberdayaan Desa Mitra PNJ dalam kegiatan Pengabdian Kepada Masyarakat berbasis Program Studi yang berjudul "Peduli dan Pencegahan COVID-19 di RT 009, RW 016, Kelurahan Bakti Jaya, Kecamatan Sukma Jaya, Depok" adalah warga RT 009, RW 016, Kelurahan Bakti Jaya, Kecamatan Sukma Jaya, Depok. Mitra ini bersedia bekerja sama dengan Program Studi Teknik Perancangan Jalan dan Jembatan, Jurusan Teknik Sipil PNJ untuk mewujudkan program ini. Untuk memperlancar kegiatan ini, diperlukan partisipasi mitra, yaitu:

- Menyediakan air dan listrik selama berlangsungnya kegiatan.

- Membantu dalam pembelian/ pengadaan material, sembako, masker, dan hand soap.

- Membantu Tim PKM pada saat instalasi wastafel serta pendistribusian sembako, masker, dan hand sanitizer.

- Membantu menyediakan peralatan tukang sederhana yang diperlukan.

- Bantuan masyarakat untuk terlibat aktif dalam mencegah penularan Covid-19 dengan cara rajin mencuci tangan, menggunakan hand soap, memakai masker saat sakit dan keluar rumah, meghindari kerumunan dan perkumpulan massa.

\section{Metode Pelaksanaan}

Diagram proses pelaksanaan program disajikan pada Gambar 3.

\begin{tabular}{|c|c|c|c|}
\hline INPUT & PROSES & OUTPUT & OUTCOME \\
\hline $\begin{array}{l}\text { - SDM di PNJ dalam } \\
\text { Pengabdian kepada } \\
\text { - Masyarakat } \\
\text { - SDM di Mitra Desa } \\
\text { yang bersedia ikut } \\
\text { terlibat untuk kegiatan } \\
\text { Pengabdian ini } \\
\text { - Permasalahan } \\
\text { pencegahan penularan } \\
\text { Covid-19 } \\
\text { - Permasalahan wastafel } \\
\text { umum } \\
\text { - Permasalahan } \\
\text { sembako } \\
\text { - Permasalahan masker } \\
\text { dan hand sanitizer }\end{array}$ & $\begin{array}{l}\text { - Survei pendahuluan } \\
\text { - Pembelian/ pengadaan } \\
\text { material, sembako, } \\
\text { masker, dan hand } \\
\text { sanitizer } \\
\text { - Penyediaan wastafel } \\
\text { umum } \\
\text { - Pendistribusian } \\
\text { sembako, masker, dan } \\
\text { hand sanitizer kepada } \\
\text { warga RT RT } 009 \text {, } \\
\text { RW 016, Kelurahan } \\
\text { Bakki Jaya }\end{array}$ & $\begin{array}{l}\text { - Tersedianya wastafel } \\
\text { umum yang dapat } \\
\text { digunakan warga } \\
\text { setempat } \\
\text { - Sembako, masker, dan } \\
\text { hand sanitizer yang } \\
\text { dapat digunakan oleh } \\
\text { warga di RT } 009 \text {, RW } \\
016, \text { Kelurahan Bakti } \\
\text { Jaya }\end{array}$ & $\begin{array}{l}\text { - Meningkatkan } \\
\text { kepedulian warga agar } \\
\text { selalu menjaga diri, } \\
\text { keluarga, dan } \\
\text { lingkungan setempat } \\
\text { agar terhindar dari } \\
\text { penularan Covid-19 } \\
\text { - Diharapkan tidak ada } \\
\text { lagi warga khususnnya } \\
\text { di RT 009, RW 016, } \\
\text { Kelurahan Bakti Jaya } \\
\text { yang dinyatakan } \\
\text { positif Covid-19 atau } \\
\text { menjadi korban akibat } \\
\text { Covid-19 }\end{array}$ \\
\hline
\end{tabular}

Gambar 3. Diagram Proses Program Pemberdayaan Desa Mitra PNJ

Uraian kegiatan Program Pemberdayaan Desa Mitra PNJ yang akan dikerjakan dalam waktu 2 (dua) bulan seperti diagram pada Gambar 4 . Uraian dari tahapan tersebut adalah sebagai berikut:

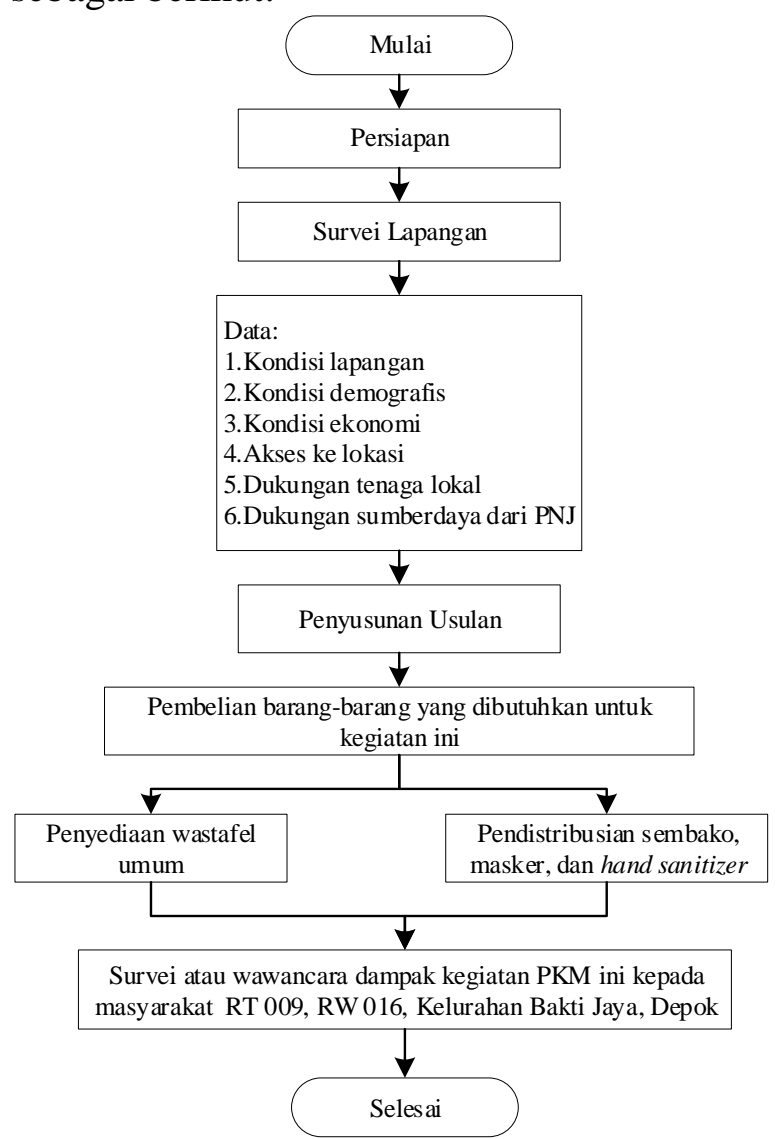

Gambar 4. Uraian Program Pemberdayaan Desa Mitra PNJ

1) Persiapan 
Persiapan dilakukan di PNJ yaitu dengan membentuk Tim Pengabdian Kepada Masyarakat berbasis Program Studi Teknik Perancangan Jalan dan Jembatan. Panitia akan memutuskan lokasi sesuai dengan usulan yang masuk berdasarkan kriteria yang ditetapkan bersama. Usulan dengan penilaian kriteria terbaik yang akan dipilih untuk diimplementasikan pelaksanaannya.

2) Survey Lapangan ke desa mitra

Tim Pengabdian Kepada Masyarakat Program Studi Teknik Perancangan Jalan dan Jembatan berangkat menuju lokasi desa mitra yaitu di di RT 009, RW 016, Kelurahan Bakti Jaya, Kecamatan Sukma Jaya, Depok. Di lapangan, tim menemui perangkat desa dan masyarakat setempat untuk membahas permasalahan yang terjadi di lapangan serta mencari solusinya.

3) Inventarisasi Data

Untuk melakukan penanganan permasalahan, diperlukan data-data, diantaranya adalah:

a. Kondisi lapangan

b. Kondisi demografis

c. Kondisi ekonomi

d. Akses ke lokasi

e. Dukungan tenaga lokal

f. Dukungan sumberdaya dari PNJ

4) Penyusulan Usulan

Berdasarkan kondisi lapangan hasil survey serta inventarisasi data yang sudah dilakukan, maka disusunlah Usulan Program Pemberdayaan Desa Mitra sesuai dengan Panduan dari DIKTI.

5) Pembelian barang-barang yang dibutuhkan untuk kegiatan ini.

Pembelian barang-barang untuk pembuatan wastabel portabel dilakukan oleh Tim Pengbadian kepada Masyarakat dari Prodi TPJJ PNJ beserta dengan wakil dari Mitra.

6) Penyediaan wastabel umum

Perwakilan dosen, mahasisiwa Prodi TPJJ PNJ bersama dengan perwakilan warga setempat akan bahu-membahu dalam pemasangan wastabel umum di,
Kelurahan Bakti Jaya, Kecamatan Sukma Jaya, Depok. Wastafel rencananya akan ditempatkan di Masjid At Taubah yang ada di RT 009, RW 016 untuk memudahkan penyediaan air bersihnya.

7) Pendisitribusian sembako, masker, dan hand sanitizer

Pendistribusian sembako, masker, dan hand sanitizer ini dilakukan oleh beberapa orang perwalikan dari Prodi Teknik Perancangan Jalan dan Jembatan, PNJ dengan beberapa warga warga RT 009, RW 06, Kelurahan Bakti Jaya, Depok. Jumlah orang yang terlibat kegiatan ini perlu dibatasi mengingat situasi yang tidak memungkinkan saat ini demi menghindari hal-hal yang tidak diinginkan selama kegiatan PKM ini berlangsung. Selain itu pembatasan ini juga dilakukan untuk mengikuti anjuran dari Pemerintah Kota Depok untuk melakukan pembatasan jumlah orang dalam suatu kerumanan.

8) Survei atau wawancara tentang dampak kegiatan PKM ini kepada warga RT 009, RW 06, Kelurahan Bakti Jaya, Depok

Survei atau wawancara tentang dampak kegiatan PKM direncanakan secara online melalui aplikasi google form. Link pengisian survei akan diberikan oleh Tim PKM Prodi Teknik Perancangan Jalan dan Jembatan, PNJ kepada pejabat RT setempat untuk dapat dibagikan dan disi oleh warga RT 009, RW 06, Kelurahan Bakti Jaya, Depok. Kemudian data ini akan diolah untuk Tim PKM Prodi Teknik Perancangan Jalan dan Jembatan, PNJ untuk membuat luaran dalam bentuk Jurnal Politeknik atau Warta Politeknik Negeri Jakarta.

Pembangunan wastabel umum, pemberian masker dan hand sanitizer ini bertujuan untuk mencegah penularan Covid-19 sehingga tidak timbul korban lagi yang dinyatakan positif Covid-19. Sedangkan pemberian sembako kepada warga yang membutuhkan di RT ini bertujuan untuk membantu para warga 
yang kesulitan mendapatkan bahan pokok akibat adanya Covid-19 ini.

\section{Hasil Dan Pembahasan}

Uraian kegiatan Program Pemberdayaan Desa Mitra PNJ yang sudah dikerjakan adalah sebagai berikut:

1) Persiapan

Persiapan dilakukan dengan mengadakan rapat terlebih dahulu dengan Tim Pengabdian Kepada Masyarakat untuk pembagian tugas. Pembagian tugas dilakukan untuk pembuatan wastafel, pembelian sembako, masker, hand soap, serta pembuatan banner. Selain itu juga dipersiapkan konsumsi pada saat pelaksanaan, daftar hadir, dan kuisioner kepuasan masyarakat atas kegiatan yang sudah dilaksanakan.

2) Kunjungan Lapangan ke desa mitra

Tim Pengabdian Kepada Masyarakat Program Studi Teknik Perancangan Jalan dan Jembatan berangkat menuju lokasi desa mitra yaitu di di RT 009, RW 016, Kelurahan Bakti Jaya, Kecamatan Sukma Jaya, Depok untuk membicarakan penempatan wastafel dan mekanisme pelaksanaan pada hari pembagian sembako nantinya. Pembagian sembako diberikan kepada warga yang sudah dipilih oleh Ketua RT sesuai dengan kondisi mereka yang sangat terdampak Covid-19. Kupon pengambilan sembako dipersiapkan yang akan dibagikan nanti sehai sebelum pembagian sembako.

3) Pembelian barang-barang yang dibutuhkan untuk kegiatan ini

Pembelian barang-barang untuk pembuatan wastabel portabel dilakukan oleh Tim Pengbadian kepada Masyarakat dari Prodi TPJJ PNJ beserta dengan wakil dari Mitra.

4) Pemasangan wastafel

Setelah wastafel selesai, kemudian diangkut ke lokasi pengabdian. Perwakilan dosen, mahasisiwa Prodi
TPJJ PNJ bersama dengan perwakilan warga setempat bahu-membahu dalam pemasangan wastafel di, Kelurahan Bakti Jaya, Kecamatan Sukma Jaya, Depok. Wastafel rencananya ditempatkan di Masjid At Taubah yang ada di RT 009, RW 016 untuk memudahkan penyediaan air bersihnya. Ketersediaan wastafel umum di lingkungan masyarakat dapat ini diharapkan dapat mengurangi penularan virus Covid-19 (Jamkesnews, 2020). Serah terima dilakukan dari Ketua Pelaksana PKM dan Ketua RT 009, RW 016.seperti tampak pada Gambar 5.

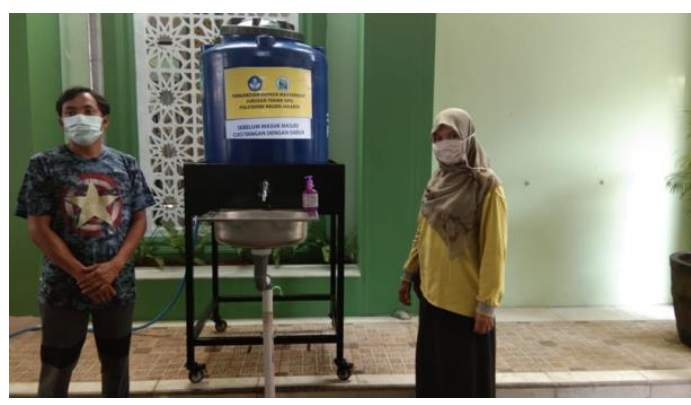

Gambar 5. Penyediaan Wastafel Umum

Dalam kegiatan ini permakilan mahasiswa prodi D4 TPJJ juga mensimulasikan penggunakaan wastafel umum seperti yang ditunjukkan oleh Gambar 6.

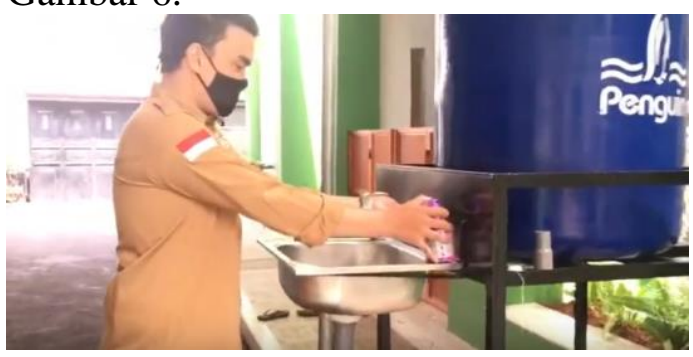

Gambar 6. Simulasi Penggunaan Wastafel Umum oleh Mahasiswa D4 TPJJ PNJ

5) Pendisitribusian sembako, masker, dan hand soap

Pendistribusian sembako, masker, dan hand soap ini dilakukan oleh beberapa orang perwalikan dari Prodi Teknik Perancangan Jalan dan Jembatan, PNJ dengan beberapa warga warga RT 009, RW 06, Kelurahan Bakti Jaya, Depok. Jumlah orang yang terlibat kegiatan ini perlu dibatasi mengingat situasi yang 
tidak memungkinkan saat ini demi menghindari hal-hal yang tidak diinginkan selama kegiatan PKM ini berlangsung. Selain itu pembatasan ini juga dilakukan untuk mengikuti anjuran dari Pemerintah Kota Depok untuk melakukan pembatasan jumlah orang dalam suatu kerumanan.

Pemberian sembako ini diharapkan dapat membantu kebutuhan pokok Warga di RT ini selama beberapa waktu sehingga dapat meringankan beban warga terutama yang kehilangan pemasukan harian mereka akibat diterapkannya PSBB. Masker juga dapat mengurangi penularan virus korona karena mencegah percikan yang disebabkan oleh percikan tetesan dan aerosol orang yang positif Covid-19 (Leung, 2020). Hand soap juga dibutuhkan untuk mengurangi resiko tertular Covid-19 saat/setelah tangan bersentuhan dengan benda yang kemungkinan terkontaminasi oleh Covid-19 (Pranita, 2020).

Pada kegiatan PKM ini Ketua Pengabdian Kepada Masyarakat Prodi D4 TPJJ, menyerahkan paket sembako dimana di dalamnya juga berisi masker dan hand soap kepada perwaklian RT setempat seperti yang ada pada Gambar 7.

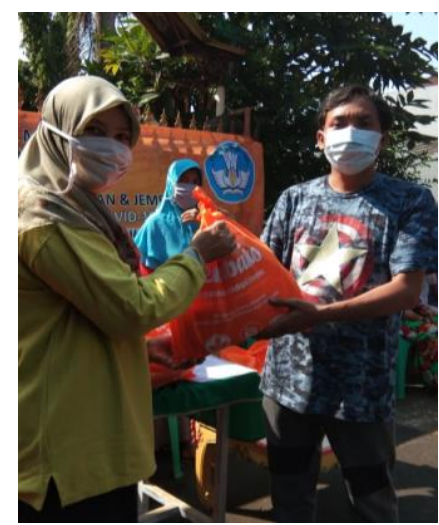

Gambar 7. Penyerahan Paket Sembako oleh Ketua PKM Prodi D4 TPJJ

Warga setempat sangat antusias sekali dalam kegiatan ini. Mereka rela mengantri untuk juga mendapatkan paket sembako ini (lihat Gambar 8.).

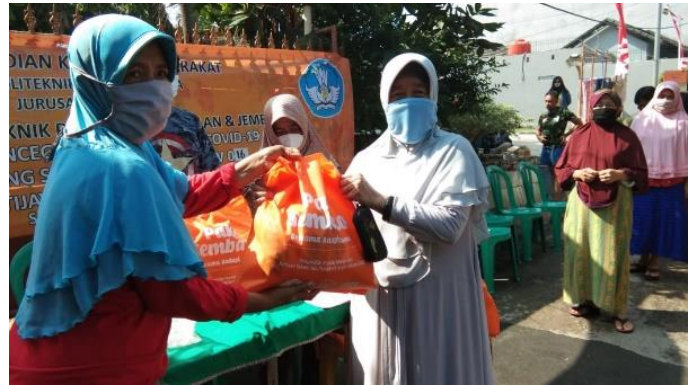

Gambar 8. Antrian Warga saat Pembagian Paket Sembako

6) Survei atau wawancara tentang dampak kegiatan PKM ini kepada warga RT 009, RW 06, Kelurahan Bakti Jaya, Depok

Hasil survei melalui pengisian google form dan wawancara tentang dampak kegiatan PKM ini kepada warga RT 009, RW 06, Kelurahan Bakti Jaya, Depok ditunjukkan pada Tabel 1.

\begin{tabular}{|c|c|c|c|c|c|}
\hline No & Pertanyaan & Setuju & $\begin{array}{l}\text { Sangat } \\
\text { Setuju }\end{array}$ & $\begin{array}{c}\text { Persentase } \\
\text { Setuju }\end{array}$ & \begin{tabular}{|c} 
Persentase \\
Sangat \\
Setuju
\end{tabular} \\
\hline 1 & \begin{tabular}{|l|} 
Staff Jurusan \\
Teknik Sipil \\
merespon \\
kebutuhan instansi/ \\
perusahaan dengan \\
tepat dan \\
profesional \\
\end{tabular} & 44 & 47 & $48,35 \%$ & $51,65 \%$ \\
\hline 2 & \begin{tabular}{|l} 
Proses pelaksanaan \\
kegiatan dengan \\
tanggap dan cepat
\end{tabular} & 45 & 46 & $49,45 \%$ & $50,55 \%$ \\
\hline 3 & \begin{tabular}{|l|} 
Staff Jurusan \\
Teknik Sipil \\
memberikan \\
pendampingan/bant \\
uan terhadap \\
instansi kami saat \\
dibutuhkan \\
\end{tabular} & 45 & 46 & $49,45 \%$ & $50,55 \%$ \\
\hline 4 & $\begin{array}{l}\text { Kerjasama/kegiatan } \\
\text { ini sesuai dengan } \\
\text { harapan }\end{array}$ & 47 & 44 & $51,65 \%$ & $48,35 \%$ \\
\hline 5 & \begin{tabular}{|l|} 
Kami mendapatkan \\
hal yang berguna \\
dari kerjasama \\
antara institusi kami \\
dan Jurusan Teknik \\
Sipil
\end{tabular} & 25 & 66 & $27,47 \%$ & $72,53 \%$ \\
\hline 6 & \begin{tabular}{|l|} 
Kerjasama antara \\
Jurusan Teknik Sipil \\
dengan Instansi \\
kami telah kami \\
implementasikan \\
dengan kegiatan \\
yang sesuai dengan \\
perjanjian yang \\
telah kami sepakati \\
bersama
\end{tabular} & 64 & 26 & $71,11 \%$ & $28,89 \%$ \\
\hline 7 & \begin{tabular}{|l} 
Pelaporan akhir \\
dari hasil kegiatan \\
kerjasama telah di \\
buat dan \\
dikomunikasikan \\
dengan kami. \\
\end{tabular} & 42 & 48 & $46,67 \%$ & $53,33 \%$ \\
\hline 8 & $\begin{array}{l}\text { Kami akan kembali } \\
\text { ke Jurusan Teknik } \\
\text { Sipil di masa } \\
\text { mendatang untuk } \\
\text { kerjasama/acara } \\
\text { lain }\end{array}$ & 29 & 61 & $32,22 \%$ & $67,78 \%$ \\
\hline \multicolumn{4}{|c|}{ Rata-rata } & $47,05 \%$ & $52,95 \%$ \\
\hline
\end{tabular}


Ada 8 pertanyaan yang telah diberikan kepada Warga di RT 009. Dari 8 pertanyaan yang telah diberikan kepada 91 responden, rata-rata sebesar $52,95 \%$ responden menjawab sangat setuju dan $47,05 \%$ responden menjawab setuju atas diadakannya kegiatan PKM oleh Prodi D4 Teknik Perancangan Jalan dan Jembatan. Jadi, berdasarkan hasil survei pada Tabel 1, Warga di RT 009 menunjukkan respon yang positif terhadap diadakannya kegiatan PKM.

\section{Kesimpulan}

Kegiatan Pengabdian kepada Masyarakat ini sangat besar manfaatnya dirasakan oleh warga di RT 09/RW 016 Kelurahan Bakti Jaya, Sukmajaya, Depok. Hasil survey menunjukkan hampir $100 \%$ responden menyatakan setuju dan sangat setuju dengan kegiatan ini. Diharapkan kegiatan ini dapat diikuti oleh lembaga atau instansi lain sehingga dampak yang ditimbulkan akibat covid19 dapat meringankan beban warga masyarakat.

\section{Ucapan Terima Kasih}

Kami sebagai Tim pelaksana
kegiatan PKM mengucapkan
terimakasih kepada Unit Penelitian dan
Pengabdian Masyarakat (UPPM)
Politeknik Negeri Jakarta atas dukungan
finansial pada kegiatan Program
Kemitraan Masyarakat (PKM) ini. Apresiasi yang tinggi kepada Ketua RT 09/RW 016 beserta segenap warga yang sudah mendukung dan berpartisipasi aktif dalam kegiatan ini. Selain itu Kami juga berterimakasih atas bantuan tenaga, waktu, dan pikiran dari KPS TPJJ, rekan-rekan Dosen, dan Mahasisw yang sudah membantu terlaksananya kegiatan ini.

\section{Daftar Pustaka}

[1] Google Map. (2020). Retrieved from https://www.google.com/maps: https://www.google.com/maps/place /Bakti+Jaya,+Sukmajaya,+Depok+ City,+West+Java/@ $6.3785763,106.8352833,14.29 \mathrm{z} /$ data $=! 4 \mathrm{~m} 5 ! 3 \mathrm{~m} 4 ! 1 \mathrm{~s} 0 \times 2 \mathrm{e} 69 \mathrm{eb} 89 \mathrm{cdda} 869$ 9:0x2d1778155d676919!8m2!3d$6.3796609 ! 4 \mathrm{~d} 106.8509389$

[2] Iqbal, B. M. (2020, 04 15). Retrieved from https://berita.depok.go.id/: https://berita.depok.go.id/photo/pen gawasan-penerapan-psbb-disimpang-ramanda-margonda- 2424

[3] Ita. (2020, April 7). Retrieved from https://news.detik.com/: https://news.detik.com/abcaustralia/d-4968434/maskerterbukti-mengurangi-penyebaranflu-dan-beberapa-jenis-virus-corona

[4] Jamkesnews. (2020, Maret 31). https://www.jamkesnews.com/jamk esnews. Retrieved from https://www.jamkesnews.com: https://www.jamkesnews.com/jamk esnews/berita/detail/nws/20074/202 00331/ajak-masyarakat-rajin-cucitangan-bpjs-kesehatan-metrosediakan-wastafel-portable

[5] Leung, N. C. (2020). Respiratory virus shedding in exhaled breath and efficacy of face masks. Nature Medicine.

[6] Mantalean, V. (2020, 03 26). https://megapolitan.kompas.com/.

Retrieved from www.kompas.com: https://megapolitan.kompas.com/rea d/2020/03/26/19515941/dataterbaru-covid-19-di-depok-positifcovid-19-bertambah-satuorang? page $=2$

[7] Pemerintah Kota Depok. (2020, 04 13). https://ccc-19.depok.go.id/. Retrieved from depok.go.id: https://ccc-19.depok.go.id/

[8] Pranita, E. (2020, April 8). Retrieved from https://www.kompas.com/: https://www.kompas.com/sains/rea d/2020/04/08/190200623/khawatirterinfeksi-corona-ini-11-cara-agartidak-tertular-covid-19. 